\title{
Mammalian Metallothionein-2A and Oxidative Stress
}

\author{
Xue-Bin Ling ${ }^{\dagger}$, Hong-Wei Wei ${ }^{\dagger}$, Jun Wang, Yue-Qiong Kong, Yu-You Wu, Jun-Li Guo, \\ Tian-Fa Li * and Ji-Ke Li * \\ Department of Cardiovascular Institute, Affiliated Hospital of Hainan Medical College, \\ Haikou 570102, China; xuebin192006@163.com (X.-B.L.); aida1860@163.com (H.-W.W.); \\ doctorwangjun@126.com (J.W.); kongyueqiong1@medmail.com.cn (Y.-Q.K.); \\ wuyuyou76@163.com (Y.-Y.W.); guoj179@163.com (J.-L.G.) \\ * Correspondence: litf79997@aliyun.com (T.-F.L.); jike0335@163.com (J.-K.L.); \\ Tel.: +86-898-6652-8126 (T.-F.L. \& J.-K.L.) \\ + These authors contributed equally to this work.
}

Academic Editors: Masatoshi Maki and Charles J. Malemud

Received: 21 May 2016; Accepted: 24 August 2016; Published: 6 September 2016

\begin{abstract}
Mammalian metallothionein-2A (MT2A) has received considerable attention in recent years due to its crucial pathophysiological role in anti-oxidant, anti-apoptosis, detoxification and anti-inflammation. For many years, most studies evaluating the effects of MT2A have focused on reactive oxygen species (ROS), as second messengers that lead to oxidative stress injury of cells and tissues. Recent studies have highlighted that oxidative stress could activate mitogen-activated protein kinases (MAPKs), and MT2A, as a mediator of MAPKs, to regulate the pathogenesis of various diseases. However, the molecule mechanism of MT2A remains elusive. A deeper understanding of the functional, biochemical and molecular characteristics of MT2A would be identified, in order to bring new opportunities for oxidative stress therapy.
\end{abstract}

Keywords: metallothionein-2A; oxidative stress; mitogen-activated protein kinases; reactive oxygen species

\section{Introduction}

Mammalian metallothioneins (MTs) are low molecular mass (6-7 kDa) proteins, which become a big family of metal-binding and metal-absorbing, cysteine-rich molecules [1,2]. Human MTs consist of 11 functional isoforms: MT-1 (A, B, E, F, G, H, M, and X), MT-2 (known as MT2A), MT-3, and MT-4, and furthermore both MT-1 and MT2A are expressed in various organs, tissues, and cultured cells, while MT-3 is expressed mainly in the brain and MT-4 most abundant in certain epithelial tissues [3]. Frankly, although MT-1 and MT2A have been largely studied together, MT2A have specific functions in regulating autophagy and apoptosis [4], and increasing risk of prostate cancer [5], as well as ductal breast cancer [6]. MT2A is composed of 61 amino acids and characterized by low molecular weight $(7 \mathrm{kDa})$, high cysteine content $(30 \%)$ and lack of aromatic amino residues [7]. The binding metal of apoMT2A could form $\alpha$-domain and $\beta$-domain, promoting convergence to the dumbbell-shaped conformation [8] (Figure 1). The function of MT2A is to regulate metal homeostasis, detoxification, oxidative stress, immune defense, cell cycle progression, cell proliferation and differentiation, and angiogenesis [9-13]. Importantly, MT2A could regulate MAPKs and play a crucial pathophysiological role in anti-oxidation, anti-apoptosis, anti-inflammation [14-17]. Reactive oxygen species (ROS) are a class of chemically reactive metabolites including superoxide anion $\left(\mathrm{O}_{2}{ }^{\bullet-}\right)$, hydroxyl radical $\left({ }^{\bullet} \mathrm{OH}\right)$, peroxynitrite $\left(\mathrm{ONOO}^{-}\right)$and hydrogen peroxide $\left(\mathrm{H}_{2} \mathrm{O}_{2}\right)$, which could cause protein dysfunction and DNA damage, leading to gene mutations and cell death $[18,19]$. In recent years, ROS have generally been described as second messengers because of cellular signaling cascades and pathophysiological processes, such as proliferation, gene expression, adhesion, differentiation, senescence, apoptosis and 
necrosis [20,21], which are mediated by activated MAPKs [22-25]. Massive studies have revealed that oxidative stress played an important role in the pathogenesis of various diseases, such as coronary heart diseases (CHDs) [26-28], neurodegenerative disorders [29,30], cancer [31-33], and aging [34,35]. Overall, more evidences have indicated that MT2A, as a free radical scavenger, might protect cells and tissues from oxidative stress. Admittedly, present review mainly focuses on total MT rather than its subtypes, but we can presume that MT2A possibly has similar function. Consequently, this review summarizes the relationship between MT2A and oxidative stress.

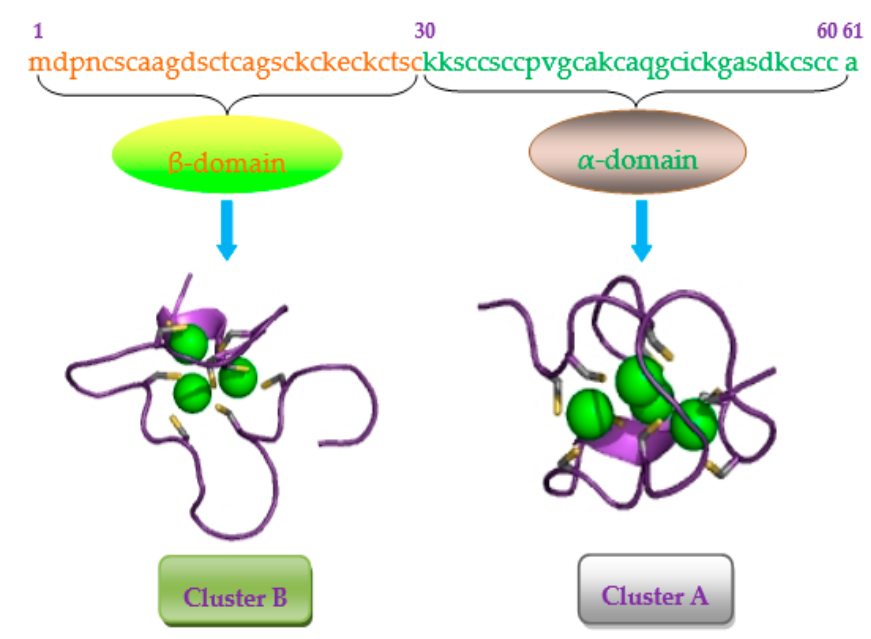

Figure 1. Structure of human metallothionein-2 (MT-2). Amino acid sequence and 3D structure were retrieved from UniProt (P02795). Class I MT2 contains 2 metal-binding domains: four divalent ions are chelated within cluster $\mathbf{A}$ of the $\alpha$-domain and are coordinated via cysteinyl thiolate bridges to 11 cysteine ligands. Cluster $\mathbf{B}$, the corresponding region within the $\beta$-domain, can ligate three divalent ions to 9 cysteines. The 3D structures show that cluster A could bind three metal ions $\left(\mathrm{Cd}^{2+}\right)$, and cluster B could bind four metal ions $\left(\mathrm{Cd}^{2+}\right)$, respectively.

\section{Metallothionein-2A (MT2A) Gene Expression Regulation}

MT2A could be influenced by $\mathrm{Zn}$ in human lymphocytes [36]. It is up-regulated during oxidative stress and hypoxia/reoxygenation (H/R) with the increasing levels of $\mathrm{ROS}$ [37], $\mathrm{H}_{2} \mathrm{O}_{2}$ [38], and various metal ions, such as $\mathrm{Cd}^{2+}$ and $\mathrm{Cu}^{+}$[39]. MT2A promoter region contains metal responsive elements, glucocorticoid responsive elements, antioxidant responsive elements, cAMP responsive elements, tissue plasminogen activator-responsive elements and interferon responsive elements. The core promoter region of MT2A contains single nucleotide polymorphism, with $87 \%$ homozygote typical (AA) and $12.3 \%$ heterozygote (AG) [40]. MT2A is severely suppressed by knockdown of metal responsive element-binding transcription factor-1 [41].

\section{MT2A Function}

\subsection{Anti-Oxidative Stress Injury}

\subsubsection{The Role of $\mathrm{Zn}$}

MT2A is a powerful scavenger of free radicals through its cysteine residues [15]. It is a $\mathrm{Zn}$ chelator when the amount of $\mathrm{Zn}$ is excessive and as a scavenger of ROS when oxidative stress is elevated [37]. The binding Zn of apoMT would maintain the stability of MT [42], and oxidative stress could also trigger $\mathrm{Zn}$ to integrate with apoMT [43]. Unfortunately, no further studies focusing on MT2A have been performed. Low dose of $\mathrm{Zn}\left(50 \mu \mathrm{M} \mathrm{ZnSO}_{4}\right)$ could up-regulate MT2A expression in reducing cytotoxicity through inhibiting oxidative stress and DNA damage [44], whereas the high dose $(100 \mu \mathrm{M}$ $\mathrm{ZnSO}_{4}$ ) is responsible for neurotoxicity through ERK1/2 [45]. MT2A is capable of binding $\mathrm{Zn}^{2+}$, 
known as $\mathrm{Zn}_{7} \mathrm{MT} 2 \mathrm{~A}$, which affects ionic homeostasis and subsequent neurotoxicity of cultured cortical neurons [10]. The characterization of the metal-binding abilities of MT2A shows a clear preference towards $\mathrm{Zn}^{2+}$ coordination, compared to $\mathrm{Cd}^{2+}$ and $\mathrm{Cu}^{+}[39]$.

\subsubsection{MT2A and Other Antioxidants}

Intracellular antioxidants commonly include glutathione (GSH), heme oxygenase-1 (HO-1), superoxide dismutase- 1 and triphosphopyridine nucleotide (NAPDH) [46]. MT2A could create a new pool of thiol in cell cytosol which could attenuate the damaging effect of GSH depletors [47]. The ability of MT2A to scavenge free ${ }^{\bullet} \mathrm{OH}$ and peroxyl radicals is found to be 100 -fold higher than that of GSH [48]. Both MT2A and HO-1 are increased along with ROS during oxidative stress [49]. Moreover, MT-1/2 double knockout cells would adapt to the expression of HO-1 [50]. Additionally, MT could mediate phosphorylate extracellular signal-regulated kinases (ERK), and control ROS through regulating HO-1 [51].

\subsection{Anti-Apoptosis}

A wide range of adverse stimuli, such as oxidative stress could cause cell apoptosis [21]. MT2A reduces adriamycin-induced myocardial injury through inhibition of oxidative stress-mediated mitochondrial cytochrome-c release and activated caspase-3 [47], protects human umbilical vein endothelial cells from lipopolysaccharide (LPS)-associated apoptosis, and also influences cellular behaviors such as proliferation and chemotaxis by binding to membrane receptors [52]. MT2A could also protect endoplasmic reticulum (ER) stress-induced cardiac failure associated with attenuation of myocardial apoptosis [53]. Knockdown of MT2A could down-regulate Zn level and affect cell apoptosis [4]. Moreover, MT2A is a protective protein from apoptosis by down-regulating the expression of Bax, caspase-3, caspase-9, and caspase-12 [4,54].

\subsection{Anti-Inflammation}

MT2A could regulate cell inflammatory response through inhibition of nuclear factor- $\mathrm{k} B$ (NF-KB) [55], and endothelial-overexpressed LPS-associated factor-1 (EOLA1) [56]. Inflammatory cytokines are released by oxidative stress [57], whereas MT2A could inhibit the activation of pro-inflammatory cytokines, such as IL-6, IL-12 and TNF- $\alpha$ [15]. MT-1/2 knockout would significantly aggravate renal oxidative damage and inflammation induced by intermittent hypoxiavia Nrf2 signaling pathway [58].

\section{MT2A and Oxidative Stress}

\subsection{Subcellular Changes}

\subsubsection{Mitochondrial Stress}

Oxidative stress-mediated damage to mitochondrial DNA could be observed in patients with diabetes mellitus and atherosclerosis [59]. MT2A exerts antioxidant effects against mitochondrial superoxide [60]. Over expression of MT2A can decrease oxygen consumption, down-regulate cellular ATP levels and decrease oxidative phosphorylation capacity, and interact with mitochondrial complexes indirectly, which might be involved in the inhibition of certain respiratory enzymes via metal binding [61]. MT2A could suppress ischemia/reperfusion (I/R)-induced myocardial apoptosis mediated by mitochondrial stress [62] (Figure 2). As for downstream signaling, intrinsic apoptotic signaling leads to mitochondrial membrane permeabilization and releases cytochrome-c into the cytosol through JNK signal [63]. 


\subsubsection{ER Stress (ERS)}

ERS stimulates autophagy in a JNK-dependent manner and promotes cell survival during oxidative stress [64]. MT2A could suppress the expression of CCAAT/enhancer-binding protein (C/EBP) homologous protein (CHOP) during Ang II-induced ERS [65] (Figure 2). ERS augments left ventricular diameter, suppresses heart contractility, and induces liver injury, which are significantly attenuated or ablated by MTs [66,67]. Additionally, ERS leads to accumulation of unfolded proteins in ER, which could activate multiple signaling pathways including JNK, p38 and NF-KB $[68,69]$.

\subsubsection{Lysosomal Membrane Permeabilization (LMP) Stress (LMPS)}

Oxidative stress could induce LMP through activation of lysosomal hydrolytic enzymes [70], which causes apoptosis [71]. MT-1/2A up-regulation has been reported to protect against LMP induced by various kinds of oxidative stress [72]. Lysosomal delivery of up-regulated MT2A is the key mechanism by which autophagy protects cells against LMPS [73] (Figure 2). LMPS is associated with activation of MAPKs, for instance, JNK has an important pro-apoptotic function, which mediates the upstream of LMP and phosphorylation [63].

\subsubsection{Biological Membrane Lipid Peroxidation Injury (LPI)}

MT2A could inhibit LPI and improve recovery after transient brain I/R in rats [74] and other researches have demonstrated that LPI increased by I/R-induced myocardial injury are dramatically decreased in MT-overexpressing mice and the oxidative damage in the lipid membranes is related to lipid peroxide (LPO)and MT levels [62] (Figure 2).

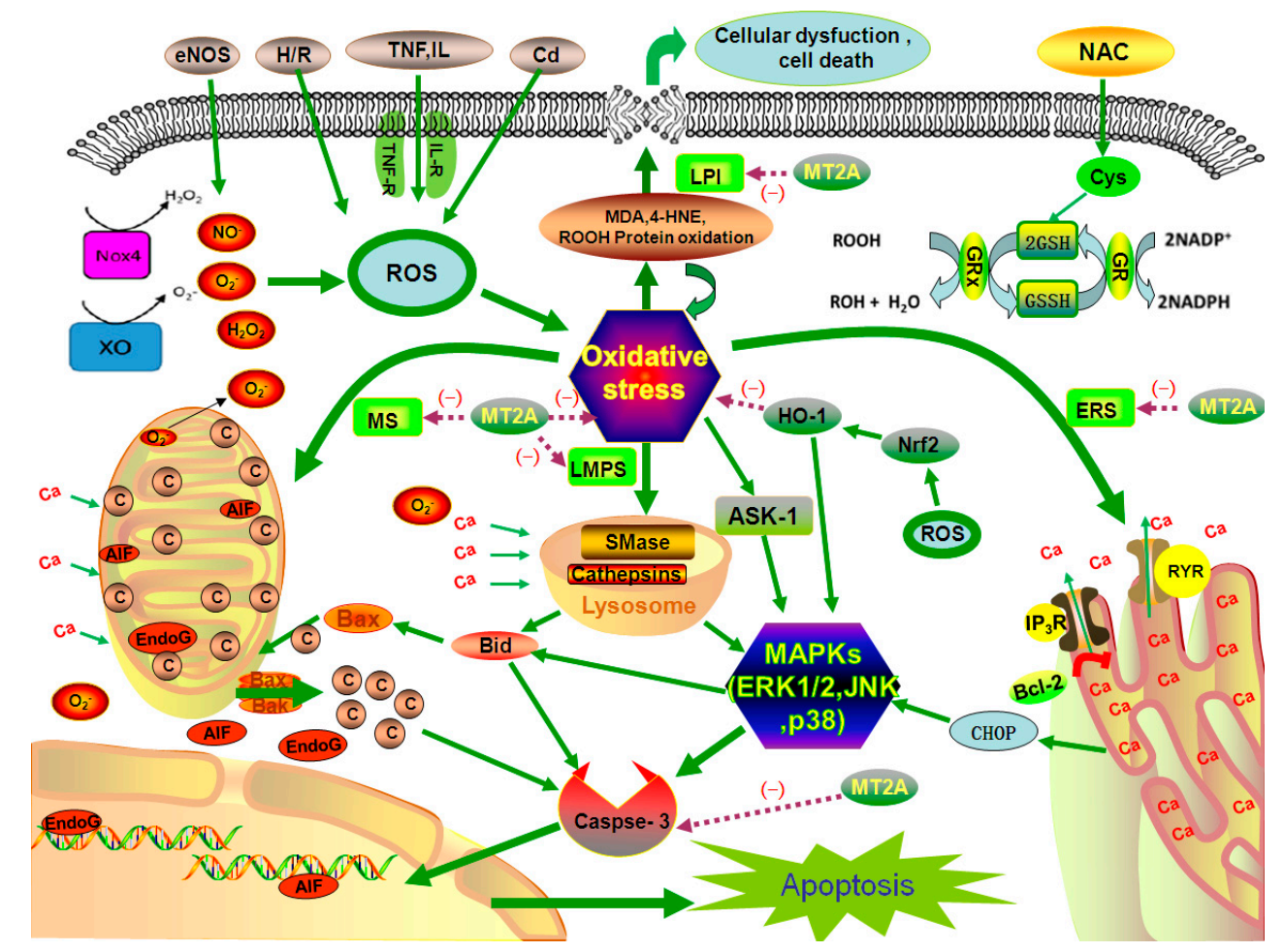

Figure 2. Interactions of subcellular structure during oxidative stress and activation cell apoptosis pathway through mitogen-activated protein kinases (MAPKs). Mammalian metallothionein-2A (MT2A) might inhibit oxidative stress through four subcellular structures. Mitochondrial Stress-MS, Endoplasmic Reticulum Stress_ERS, Lysosomal Membrane Permeabilization Stress-LMPS, Lipid Peroxidation Injury-LPI, Endothelial Nitric Oxide Synthase-eNOS: (green arrows $\longrightarrow$ : caused definitely, brown dotted arrows $\cdots \cdot \rightarrow$ : caused indefinitely, Inhibit(-)). 


\subsection{The Role of MT2A in MAPKs Signals}

MAPKs comprise a family of serine/threonine phosphorylating proteins, which contain three main branches: ERK, JNK and p38 [75]. MTs play an important role in improving the LPS-induced cardiac dysfunction with activated MAPK [76] (Figure 3). However, MT plays a key role in preventing hypoxia-induced renal injury via Nrf2, owing to inactivation of AKT and ERK [58]. Arsenic trioxide could induce $\mathrm{H} 9 \mathrm{c} 2$ cell death in a dose- and time-dependent manner with a significant activation of MAPKs, but not in MT-H9c2 cells [77]. Importantly, the protective effect of MT on arsenic trioxide-induced apoptotic cell is completely recaptured in heart with a significant prevention of MAPKs [77]. In Cd-induced apoptotic cells, MT is less expressed in Cd-sensitive cells but p-JNK is increased, and a strong activator of JNK, R0318220, could reverse the Cd-sensitive phenotype in Cd-resist cells, and this research also showed that p-JNK1/2 is markedly up-regulated in $\mathrm{MT}^{-/-}$cells compared with $\mathrm{MT}^{+/+}$cells through $\mathrm{Cd}$ treatment, suggesting that MT might inhibit JNK1/2 activation [16]. Another study has indicated that the suppression of JNK is mediated by ROS [78]. Whether MT directly inhibits JNK phosphorylation or not remains elusive in present studies.

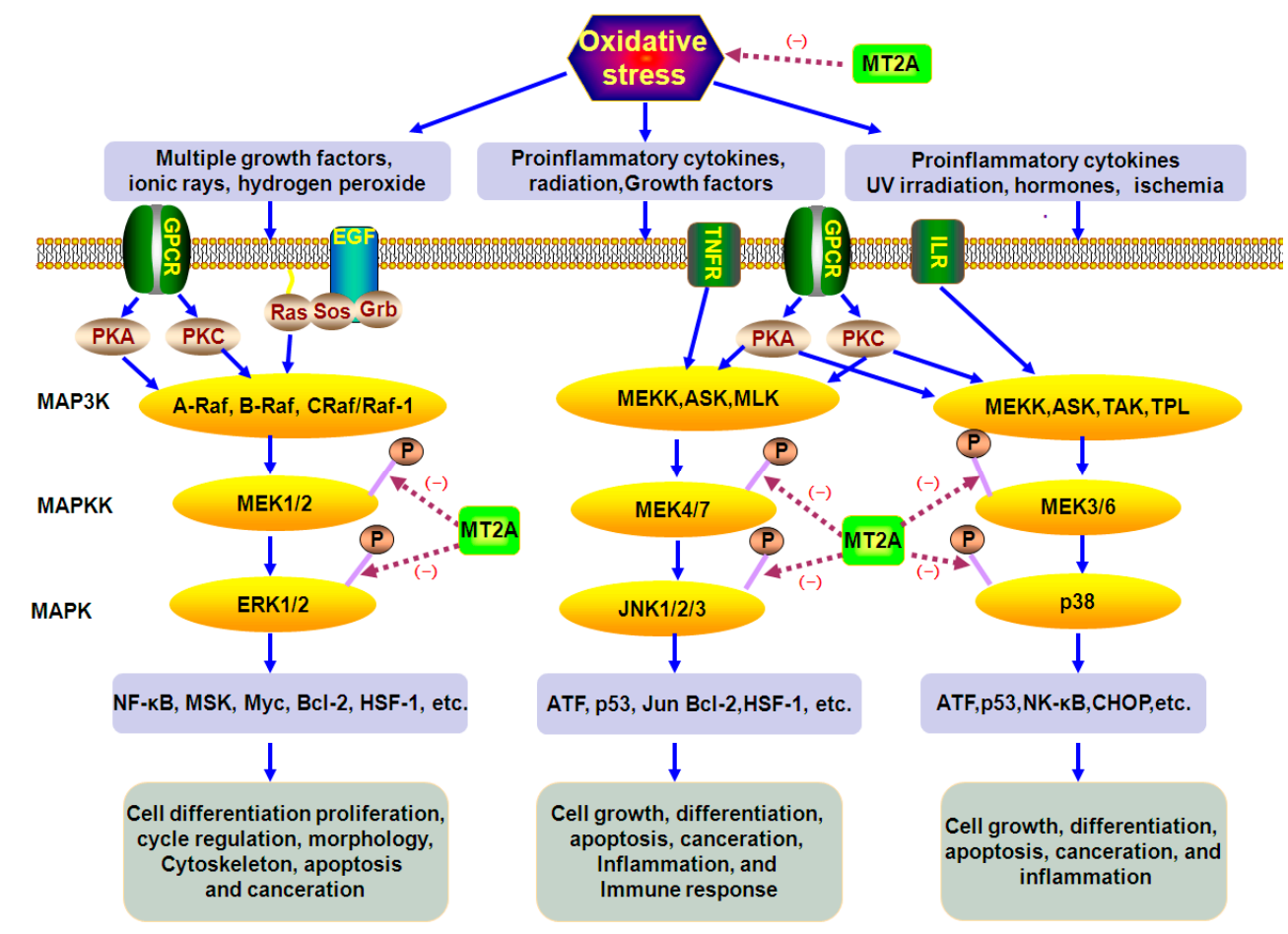

Figure 3. MAPKs pathway during oxidative stress. MAPKs pathway is typically initiated by G protein-coupled receptor or by stress stimuli, then triggers a cascade of phosphorylation reactions, and finally leads to various cell biological effects. MT2A might inhabit MAPKs in oxidative stress. (blue arrows $\longrightarrow$ : caused definitely, brown dotted arrows $\cdots \cdot \rightarrow$ : caused indefinitely, Inhibit $(-)$.)

\section{MT2A and Disease}

\subsection{Cardiovascular Disease}

MT2A is a potent antioxidant in heart [37,53,79] (Table 1). More importantly, antioxidant is shown to exert beneficial effects in hypertension, atherosclerosis, ischemic heart disease, cardiomyopathy and congestive heart failure $[17,80]$. Although the mechanism underlying myocardial protection from I/R injury through MT has not been fully understood, a large pool of evidence has demonstrated that oxidative stress is a critical mediator for myocardial damage during I/R [27,62]. MT2A might play a role in cardiovascular protection through radical scavenging activities and suppression of lipid peroxidation [81]. MT2A polymorphism is associated with atherosclerosis on coronary artery [26], 
and carotid artery [82]. The cardioprotective property of MT is involved in diabetes mellitus-, obesityand aging-induced cardiac damage [28,83]. ERS directly triggers cardiomyocyte dysfunction and MT could ablate the process through up-regulating the level of JNK phosphorylation [84]. ERS inhibitor tauroursodeoxycholic acid could reverse the process [85]. Moreover, MT is able to prevent myocardial anomalies through restoration of autophagy in hypertensive heart diseases [79].

\subsection{Nervous System Disease}

Multiple nervous system diseases are closely related to MT2A. MT2A is the most significantly up-regulated transcript in ischemic head [86], and it is a novel neuroprotective factor to prevent ischemic injury [74] (Table 1). Simultaneously, MT2A is a critical component in the maintenance of immune homeostasis, as it is demonstrated in autoimmune encephalomyelitis disease [87]. Parkinson's disease is one of the most common progressive neurodegenerative disorders with increased oxidative stress and MT2A released from astrocytes is a potent protector of dopaminergic neuron [88]. Alzheimer's disease is triggered by the deposition of insoluble extracellular b-amyloid $(\mathrm{Ab})$ plaque, and MT2A is capable of protecting against Ab aggregation and toxicity for therapeutic approach to Alzheimer's disease [10]. Additionally, MT-1/2 knockout mice would result in embryonic lethality in a model of Menkes disease (a copper efflux disease) [89].

\subsection{Cancers}

MT-1/2 deficiency predisposes mice more sensitive to early life $\mathrm{Pb}$ exposure with regard to testes tumors, renal and urinary bladder preneoplastic lesions [33]. MT2A over-expression is associated with cell proliferation in cancerous breast tissue [90], with significantly modified breast cancer risk, and cell cycle is inhibited through silencing MT2A [91]. MT2A predicts high therapeutic value in hepatocellular carcinoma [92], whereas predicts poor survival in glioblastoma multiforme [93]. MT2A might be a chemosensitive indicator in gastric cancer (GC) [94], and another study found that MT2A might play a role in suppressing tumor activity through inhibiting NF- $\mathrm{KB}$ and might be a prognostic biomarker and potential target for individual therapy of GC [95] (Table 1). MT2A polymorphismis closely correlated with neoplasm, implicated in laryngeal cancer [96]. In addition, MT2A contributes to chemotherapy resistance in osteosarcoma [97]. Finally, it has to be mentioned that the MT2A has differential outcome in various types of cancer that may be tissue or cell type dependent, just like E2 factor, including cellular proliferation, apoptosis and tumor kinetics [98].

\subsection{Aging}

MT2A is crucial for the immune efficiency during aging and age-related diseases [99]. Up-regulated expression of MT2A in kidney with aging might play a protective role, which is closely related to aging [34]. Additionally, MT2A gene polymorphisms are associated with aging in Turkey [100] (Table 1).

\subsection{Diabetes Mellitus}

MT2A could prevent diabetes-induced cardiac ERS, which contributes to prevent dilated cardiomyopathy (DCM) [65] (Table 1). MT2A plays an important role in antioxidant defense in type2 diabetes mellitus through modulating glutathione, which promotes phosphorylation of insulin receptors through enhancing transportation of glucose into cells [101]. Moreover, MT2Ais correlated to diabetic atherosclerosis in patients [102].

\subsection{Hepatal and Gastrointestinal Diseases}

It was found that MT2A is slightly more expressed in both chronic hepatitis and Wilson's disease [103] (Table 1). Furthermore, MT2A could activate human hepatic stellate cells to up-regulate 
the expression of collagenase genes, which might exert the therapeutic effect upon liver fibrosis [104]. Additionally, MT2A could prevent colonic mucosal inflammation in murine experimental colitis [105].

Table 1. Summary of MT2A in relation to disease.

\begin{tabular}{|c|c|c|}
\hline Reference & Tissue Type/Sample Size & Findings \\
\hline Chung, et al. [10] & $\begin{array}{l}\text { Rat: cortical neuron cells; treated with/without } \\
\qquad \mathrm{A} \beta_{1-40} ; n=\text { not disclosed }\end{array}$ & $\begin{array}{l}\text { MT-2A was capable of therapeutic } \\
\text { approach to AD }\end{array}$ \\
\hline Yang, et al. [26] & Human: Peripheral blood; 287CHD; 226 control & $\begin{array}{c}\text { The gene polymorphism of } \\
\text { MT2A-838G/C was correlated to CHD }\end{array}$ \\
\hline $\mathrm{Xu}$, et al. [65] & $\begin{array}{c}\text { Mice: myocytes; } 6 \text { wild-type; } 6 \text { cardiac-specific MT } \\
\text { transgenic mice; Rats: H9c2 and H9c2MT7 cells; } \\
n=\text { not disclosed }\end{array}$ & $\begin{array}{l}\text { MT2A could prevent diabetes-induced } \\
\text { cardiac ERS, which contributed to } \\
\text { prevent DCM }\end{array}$ \\
\hline Xue, et al. [37] & Rats: $\mathrm{H} 9 \mathrm{c} 2$ and H9c2MT7 cells; $n=$ not disclosed & $\begin{array}{l}\text { MT2A markedly increased oxidative } \\
\text { protection induced by } \mathrm{H} / \mathrm{R} \text { or } \mathrm{Cd} \text { toxicity } \\
\text { in rat cardiac myocytes }\end{array}$ \\
\hline Jakovac, et al. [87] & Rats: Tissues: spinal cord, liver; $\mathrm{BBH}$ and DA & $\begin{array}{l}\text { MT2A had neuroprotective role of } \\
\text { autoimmune encephalomyelitis }\end{array}$ \\
\hline Miyazaki, et al. [88] & $\begin{array}{l}\text { Mice: Tissues: astrocytes, the striatum; } \\
\text { 6-hydroxydopamine-Lesioned parkinsonian model } \\
\text { mice; control; } n=\text { not disclosed }\end{array}$ & $\begin{array}{l}\text { MT2A provided a promising therapeutic } \\
\text { strategy in Parkinson's disease }\end{array}$ \\
\hline Pan, et al. [95] & $\begin{array}{l}\text { Human: Gastric tumor tissue; } 684 \text { GCs patients } \\
\text { cohort; } 258 \text { GC patients subset }\end{array}$ & $\begin{array}{l}\text { MT2A might be a chemosensitivity } \\
\text { indicator in GC patients }\end{array}$ \\
\hline Kayaalti, et al. [100] & $\begin{array}{c}\text { Human: Peripheral blood; } 354 \text { individuals aged } \\
\text { between } 18 \text { and } 95\end{array}$ & $\begin{array}{l}\text { The IL-6-174C+ carriers and MT2A-5 } \\
\text { G-carriers might be more advantageous } \\
\text { for longevity }\end{array}$ \\
\hline Giacconi, et al. [102] & $\begin{array}{c}\text { Human: Peripheral blood; } 91 \text { Type } 2 \text { diabetes } \\
\text { patients; } 188 \text { control }\end{array}$ & $\begin{array}{l}\text { The MT2A polymorphism was associated } \\
\text { with Type } 2 \text { diabetes and atherosclerosis }\end{array}$ \\
\hline Nakazato, et al. [103] & $\begin{array}{l}\text { Human: Peripheral blood; } 18 \text { chronic hepatitis C } \\
\text { patients and } 19 \text { Wilson's disease patients; } \\
200 \text { control }\end{array}$ & $\begin{array}{c}\text { A significantly elevated MT2A was found } \\
\text { in patients with chronic hepatitis and } \\
\text { Wilson's disease }\end{array}$ \\
\hline Xu, et al. [104] & $\begin{array}{l}\text { Human: LX-2 cell from human hepatic stellate; } \\
\text { pEGFP-N1-hMT-IIA and pEGFP-N1 were } \\
\text { transfected into LX-2 cells; } n=\text { not disclosed }\end{array}$ & $\begin{array}{l}\text { Liver fibrosis might be } \\
\text { treated by MT2A }\end{array}$ \\
\hline
\end{tabular}

MT7: human MT-IIA over-expressing cardiac cell line; BBH: bovine brain homogenate rats; DA: Dark Agouti rats; IID: itai-itai disease; DCM: dilated cardiomyopathy.

\section{Conclusions}

MT2A is intimately associated with oxidative stress, mediated by subcellular pathways of mitochondria, ER, lysosomal, and lipidosome, as well as MAPKs (ERK, JNK and p38) signals.

Acknowledgments: This work was financially supported by the National Natural Sciences Foundation of China (81200150, 81460070, 81660064), Hainan Province Natural Science Foundation (20158338), Hainan Provincial Foundation for Health Department (14A210227), Cultivating Fund of Hainan Medical University (HY2014-007), Youth Innovative Talents Project of Hainan Association for Science and Technology (2015-16), Haikou Key Program of Science \& Technology (2014062), Scientific Research Foundation for the Returned Overseas of Ministry of Human Society, and Hainan Provincial Science \& Technology Key Project (KJHZ2015-27, ZDYF2016168 and ZDYF2016224).

Conflicts of Interest: The authors declare no conflict of interests.

\section{References}

1. Murakami, S.; Miyazaki, I.; Sogawa, N.; Miyoshi, K.; Asanuma, M. Neuroprotective effects of metallothionein against rotenone-induced myenteric neurodegeneration in parkinsonian mice. Neurotox. Res. 2014, 26, 285-298. [CrossRef] [PubMed]

2. Blindauer, C. Binding, Transport and Storage of Metal Ions in Biological Cells. In Metallothioneins; Maret, W., Wedd, A., Eds.; The Royal Society of Chemistry: Cambridge, UK, 2014; pp. 594-653.

3. Kimura, T.; Kambe, T. The Functions of Metallothionein and ZIP and ZnT Transporters: An Overview and Perspective. Int. J. Mol. Sci. 2016, 17, 336. [CrossRef] [PubMed]

4. Ma, H.; Su, L.; Yue, H.; Yin, X.; Zhao, J.; Zhang, S.; Kung, H.; Xu, Z.; Miao, J. HMBOX1 interacts with MT2A to regulate autophagy and apoptosis in vascular endothelial cells. Sci. Rep. 2015, 5, 15121. [CrossRef] [PubMed] 
5. Krzeslak, A.; Forma, E.; Chwatko, G.; Jozwiak, P.; Szymczyk, A.; Wilkosz, J.; Rozanski, W.; Brys, M. Effect of metallothionein 2A gene polymorphism on allele-specific gene expression and metal content in prostate cancer. Toxicol. Appl. Pharmacol. 2013, 268, 278-285. [CrossRef] [PubMed]

6. Krzeslak, A.; Forma, E.; Jozwiak, P.; Szymczyk, A.; Smolarz, B.; Romanowicz-Makowska, H.; Rozanski, W.; Brys, M. Metallothionein 2A genetic polymorphisms and risk of ductal breast cancer. Clin. Exp. Med. 2014, 14, 107-113. [CrossRef] [PubMed]

7. Vasak, M. Advances in metallothionein structure and functions. J. Trace Elem. Med. Biol. 2005, $19,13-17$. [CrossRef] [PubMed]

8. Chen, S.H.; Chen, L.; Russell, D.H. Metal-induced conformational changes of human metallothionein-2A: A combined theoretical and experimental study of metal-free and partially metalated intermediates. J. Am. Chem. Soc. 2014, 136, 9499-9508. [CrossRef] [PubMed]

9. Takahashi, S. Positive and negative regulators of the metallothionein gene (review). Mol. Med. Rep. 2015, 12, 795-799. [CrossRef] [PubMed]

10. Chung, R.S.; Howells, C.; Eaton, E.D.; Shabala, L.; Zovo, K.; Palumaa, P.; Sillard, R.; Woodhouse, A.; Bennett, W.R.; Ray, S.; et al. The native copper- and zinc-binding protein metallothionein blocks copper-mediated Abeta aggregation and toxicity in rat cortical neurons. PLoS ONE 2010, 5, e12030. [CrossRef] [PubMed]

11. Nielsen, A.E.; Bohr, A.; Penkowa, M. The balance between life and death of cells: Roles of metallothioneins. Biomark. Insights 2007, 1, 99-111. [PubMed]

12. Penkowa, M.; Caceres, M.; Borup, R.; Nielsen, F.C.; Poulsen, C.B.; Quintana, A.; Molinero, A.; Carrasco, J.; Florit, S.; Giralt, M.; et al. Novel roles for metallothionein-I + II (MT-I + II) in defense responses, neurogenesis, and tissue restoration after traumatic brain injury: Insights from global gene expression profiling in wild-type and MT-I + II knockout mice. J. Neurosci. Res. 2006, 84, 1452-1474. [CrossRef] [PubMed]

13. Miles, A.T.; Hawksworth, G.M.; Beattie, J.H.; Rodilla, V. Induction, regulation, degradation, and biological significance of mammalian metallothioneins. Crit. Rev. Biochem. Mol. Biol. 2000, 35, 35-70. [CrossRef] [PubMed]

14. Wang, Y.; Zhou, S.; Sun, W.; McClung, K.; Pan, Y.; Liang, G.; Tan, Y.; Zhao, Y.; Liu, Q.; Sun, J.; et al. Inhibition of JNK by novel curcumin analog C66 prevents diabetic cardiomyopathy with a preservation of cardiac metallothionein expression. Am. J. Physiol. Endocrinol. Metab. 2014, 306, 1239-1247. [CrossRef] [PubMed]

15. Stankovic, R.K.; Chung, R.S.; Penkowa, M. Metallothioneins I and II: Neuroprotective significance during CNS pathology. Int. J. Biochem. Cell Biol. 2007, 39, 484-489. [CrossRef] [PubMed]

16. Qu, W.; Fuquay, R.; Sakurai, T.; Waalkes, M.P. Acquisition of apoptotic resistance in cadmium-induced malignant transformation: Specific perturbation of JNK signal transduction pathway and associated metallothionein overexpression. Mol. Carcinog. 2006, 45, 561-571. [CrossRef] [PubMed]

17. Krizkova, S.; Kepinska, M.; Emri, G.; Rodrigo, M.A.; Tmejova, K.; Nerudova, D.; Kizek, R.; Adam, V. Microarray analysis of metallothioneins in human diseases-A review. J. Pharm. Biomed. Anal. 2016, 117, 464-473. [CrossRef] [PubMed]

18. Wang, Z.; Li, S.; Cao, Y.; Tian, X.; Zeng, R.; Liao, D.F.; Cao, D. Oxidative Stress and Carbonyl Lesions in Ulcerative Colitis and Associated Colorectal Cancer. Oxid. Med. Cell. Longev. 2016, 2016, 9875298. [CrossRef] [PubMed]

19. Pagel, J.I.; Deindl, E. Disease progression mediated by egr-1 associated signaling in response to oxidative stress. Int. J. Mol. Sci. 2012, 13, 13104-13117. [CrossRef] [PubMed]

20. Madureira, P.A.; Waisman, D.M. Annexin A2: The importance of being redox sensitive. Int. J. Mol. Sci. 2013, 14, 3568-3594. [CrossRef] [PubMed]

21. Cosentino-Gomes, D.; Rocco-Machado, N.; Meyer-Fernandes, J.R. Cell Signaling through Protein Kinase C Oxidation and Activation. Int. J. Mol. Sci. 2012, 13, 10697-10721. [CrossRef] [PubMed]

22. Zhu, Z.; Zhu, J.; Zhao, X.; Yang, K.; Lu, L.; Zhang, F.; Shen, W.; Zhang, R. All-Trans Retinoic Acid Ameliorates Myocardial Ischemia/Reperfusion Injury by Reducing Cardiomyocyte Apoptosis. PLoS ONE 2015, 10, e0133414. [CrossRef] [PubMed]

23. Qin, J.; Mei, W.J.; Xie, Y.Y.; Huang, L.; Yuan, Q.J.; Hu, G.Y.; Tao, L.J.; Peng, Z.Z. Fluorofenidone attenuates oxidative stress and renal fibrosis in obstructive nephropathy via blocking NOX2 (gp91phox) expression and inhibiting ERK/MAPK signaling pathway. Kidney Blood Press. Res. 2015, 40, 89-99. [CrossRef] [PubMed] 
24. Moslehi, M.; Yazdanparast, R. SK-N-MC cell death occurs by distinct molecular mechanisms in response to hydrogen peroxide and superoxide anions: Involvements of JAK2-STAT3, JNK, and p38 MAP kinases pathways. Cell Biochem. Biophys. 2013, 66, 817-829. [CrossRef] [PubMed]

25. Chen, Z.; Li, J.; Zhao, T.J.; Li, X.H.; Meng, F.G.; Mu, H.; Yan, Y.B.; Zhou, H.M. Metallothioneins protect cytosolic creatine kinases against stress induced by nitrogen-based oxidants. Biochem. J. 2012, 441, 623-632. [CrossRef] [PubMed]

26. Yang, X.Y.; Sun, J.H.; Ke, H.Y.; Chen, Y.J.; Xu, M.; Luo, G.H. Metallothionein 2A genetic polymorphism and its correlation to coronary heart disease. Eur. Rev. Med. Pharmacol. Sci. 2014, 18, 3747-3753. [PubMed]

27. Murphy, E.; Steenbergen, C. Mechanisms underlying acute protection from cardiac ischemia-reperfusion injury. Physiol. Rev. 2008, 88, 581-609. [CrossRef] [PubMed]

28. Dong, F.; Li, Q.; Sreejayan, N.; Nunn, J.M.; Ren, J. Metallothionein prevents high-fat diet induced cardiac contractile dysfunction: Role of peroxisome proliferator activated receptor gamma coactivator 1alpha and mitochondrial biogenesis. Diabetes 2007, 56, 2201-2212. [CrossRef] [PubMed]

29. Kumar, H.; Koppula, S.; Kim, I.S.; More, S.V.; Kim, B.W.; Choi, D.K. Nuclear factor erythroid 2-related factor 2 signaling in Parkinson disease: A promising multi therapeutic target against oxidative stress, neuroinflammation and cell death. CNS Neurol. Disord. Drug Targets 2012, 11, 1015-1029. [CrossRef] [PubMed]

30. Levin, E.D.; Perraut, C.; Pollard, N.; Freedman, J.H. Metallothionein expression and neurocognitive function in mice. Physiol. Behav. 2006, 87, 513-518. [CrossRef] [PubMed]

31. Starska, K.; Brys, M.; Forma, E.; Olszewski, J.; Pietkiewicz, P.; Lewy-Trenda, I.; Stasikowska-Kanicka, O.; Danilewicz, M.; Krzeslak, A. Metallothionein 2A core promoter region genetic polymorphism and its impact on the risk, tumor behavior, and recurrences of sinonasal inverted papilloma (Schneiderian papilloma). Tumour Biol. 2015, 36, 8559-8571. [CrossRef] [PubMed]

32. Seibold, P.; Hein, R.; Schmezer, P.; Hall, P.; Liu, J.; Dahmen, N.; Flesch-Janys, D.; Popanda, O.; Chang-Claude, J. Polymorphisms in oxidative stress-related genes and postmenopausal breast cancer risk. Int. J. Cancer 2011, 129, 1467-1476. [CrossRef] [PubMed]

33. Tokar, E.J.; Diwan, B.A.; Waalkes, M.P. Early life inorganic lead exposure induces testicular teratoma and renal and urinary bladder preneoplasia in adult metallothionein-knockout mice but not in wild type mice. Toxicology 2010, 276, 5-10. [CrossRef] [PubMed]

34. Leierer, J.; Rudnicki, M.; Braniff, S.J.; Perco, P.; Koppelstaetter, C.; Muhlberger, I.; Eder, S.; Kerschbaum, J.; Schwarzer, C.; Schroll, A.; et al. Metallothioneins and renal ageing. Nephrol. Dial. Transplant. 2016, in press. [CrossRef] [PubMed]

35. Swindell, W.R. Metallothionein and the biology of aging. Ageing Res. Rev. 2011, 10, 132-145. [CrossRef] [PubMed]

36. Wu, M.T.; Demple, B.; Bennett, R.A.; Christiani, D.C.; Fan, R.; Hu, H. Individual variability in the zinc inducibility of metallothionein-IIA mRNA in human lymphocytes. J. Toxicol. Environ. Health A 2000, 61, 553-567. [CrossRef] [PubMed]

37. Xue, W.; Liu, Q.; Cai, L.; Wang, Z.; Feng, W. Stable overexpression of human metallothionein-IIA in a heart-derived cell line confers oxidative protection. Toxicol. Lett. 2009, 188, 70-76. [CrossRef] [PubMed]

38. Zhang, N.; Wang, L.; Duan, Q.; Lin, L.; Ahmed, M.; Wang, T.; Yao, X. Metallothionein-I/II Knockout Mice Aggravate Mitochondrial Superoxide Production and Peroxiredoxin 3 Expression in Thyroid after Excessive Iodide Exposure. Oxid. Med. Cell. Longev. 2015. [CrossRef] [PubMed]

39. Artells, E.; Palacios, O.; Capdevila, M.; Atrian, S. Mammalian MT1 and MT2 metallothioneins differ in their metal binding abilities. Metallomics 2013, 5, 1397-1410. [CrossRef] [PubMed]

40. Kayaaltı, Z.; Söylemezoğlu, T. The polymorphism of core promoter region on metallothionein 2A-metal binding protein in Turkish population. Mol. Biol. Rep. 2009, 37, 185-190. [CrossRef] [PubMed]

41. Kukic, I.; Lee, J.K.; Coblentz, J.; Kelleher, S.L.; Kiselyov, K. Zinc-dependent lysosomal enlargement in TRPML1-deficient cells involves MTF-1 transcription factor and ZnT4 (Slc30a4) transporter. Biochem. J. 2013, 451, 155-163. [CrossRef] [PubMed]

42. Summers, K.L.; Sutherland, D.E.; Stillman, M.J. Single-domain metallothioneins: Evidence of the onset of clustered metal binding domains in Zn-rhMT 1a. Biochemistry 2013, 52, 2461-2471. [CrossRef] [PubMed]

43. Mocchegiani, E.; Giacconi, R.; Muti, E.; Cipriano, C.; Costarelli, L.; Tesei, S.; Gasparini, N.; Malavolta, M. Zinc-bound metallothioneins and immune plasticity: Lessons from very old mice and humans. Immun. Ageing 2007, 4. [CrossRef] [PubMed] 
44. Zheng, J.; Zhang, Y.; Xu, W.; Luo, Y.; Hao, J.; Shen, X.L.; Yang, X.; Li, X.; Huang, K. Zinc protects HepG2 cells against the oxidative damage and DNA damage induced by ochratoxin A. Toxicol. Appl. Pharmacol. 2013, 268, 123-131. [CrossRef] [PubMed]

45. He, K.; Aizenman, E. ERK signaling leads to mitochondrial dysfunction in extracellular zinc-induced neurotoxicity. J. Neurochem. 2010, 114, 452-461. [CrossRef] [PubMed]

46. Taguchi, K.; Motohashi, H.; Yamamoto, M. Molecular mechanisms of the Keap1-Nrf2 pathway in stress response and cancer evolution. Genes Cells 2011, 16, 123-140. [CrossRef] [PubMed]

47. Roel, M.; Rubiolo, J.A.; Ternon, E.; Thomas, O.P.; Vieytes, M.R.; Botana, L.M. Crambescin C1 Exerts a Cytoprotective Effect on HepG2 Cells through Metallothionein Induction. Mar. Drugs 2015, 13, 4633-4653. [CrossRef] [PubMed]

48. Lian, Y.; Zhao, J.; Xu, P.; Wang, Y.; Zhao, J.; Jia, L.; Fu, Z.; Jing, L.; Liu, G.; Peng, S. Protective effects of metallothionein on isoniazid and rifampicin-induced hepatotoxicity in mice. PLoS ONE 2013, 8, e72058. [CrossRef] [PubMed]

49. Yang, M.; Chitambar, C.R. Role of oxidative stress in the induction of metallothionein-2A and heme oxygenase-1 gene expression by the antineoplastic agent gallium nitrate in human lymphoma cells. Free Radic. Biol. Med. 2008, 45, 763-772. [CrossRef] [PubMed]

50. Qu, W.; Pi, J.; Waalkes, M.P. Metallothionein blocks oxidative DNA damage in vitro. Arch. Toxicol. 2013, 87, 311-321. [CrossRef] [PubMed]

51. Hwang, Y.P.; Kim, H.G.; Han, E.H.; Jeong, H.G. Metallothionein-III protects against 6-hydroxydopamineinduced oxidative stress by increasing expression of heme oxygenase-1 in a PI3K and ERK/Nrf2-dependent manner. Toxicol. Appl. Pharmacol. 2008, 231, 318-327. [CrossRef] [PubMed]

52. Lynes, M.A.; Hidalgo, J.; Manso, Y.; Devisscher, L.; Laukens, D.; Lawrence, D.A. Metallothionein and stress combine to affect multiple organ systems. Cell Stress Chaperones 2014, 19, 605-611. [CrossRef] [PubMed]

53. Yang, L.; Wang, J.; Yang, J.; Schamber, R.; Hu, N.; Nair, S.; Xiong, L.; Ren, J. Antioxidant metallothionein alleviates endoplasmic reticulum stress-induced myocardial apoptosis and contractile dysfunction. Free Radic. Res. 2015, 49, 1187-1198. [CrossRef] [PubMed]

54. Shimoda, R.; Achanzar, W.E.; Qu, W.; Nagamine, T.; Takagi, H.; Mori, M.; Waalkes, M.P. Metallothionein is a potential negative regulator of apoptosis. Toxicol. Sci. 2003, 73, 294-300. [CrossRef] [PubMed]

55. Takano, H.; Inoue, K.; Yanagisawa, R.; Sato, M.; Shimada, A.; Morita, T.; Sawada, M.; Nakamura, K.; Sanbongi, C.; Yoshikawa, T. Protective role of metallothionein in acute lung injury induced by bacterial endotoxin. Thorax 2004, 59, 1057-1062. [CrossRef] [PubMed]

56. Leng, W.; Lei, X.; Meng, H.; Ouyang, X.; Liang, Z. EOLA1 Inhibits Lipopolysaccharide-Induced Vascular Cell Adhesion Molecule-1 Expression by Association with MT2A in ECV304 Cells. Int. J. Inflamm. 2015, 2015. [CrossRef] [PubMed]

57. Oikonomou, N.; Harokopos, V.; Zalevsky, J.; Valavanis, C.; Kotanidou, A.; Szymkowski, D.E.; Kollias, G.; Aidinis, V. Soluble TNF mediates the transition from pulmonary inflammation to fibrosis. PLoS ONE 2006, 1, e108. [CrossRef] [PubMed]

58. Wu, H.; Zhou, S.; Kong, L.; Chen, J.; Feng, W.; Cai, J.; Miao, L.; Tan, Y. Metallothionein deletion exacerbates intermittent hypoxia-induced renal injury in mice. Toxicol. Lett. 2015, 232, 340-348. [CrossRef] [PubMed]

59. Fetterman, J.L.; Holbrook, M.; Westbrook, D.G.; Brown, J.A.; Feeley, K.P.; Breton-Romero, R.; Linder, E.A.; Berk, B.D.; Weisbrod, R.M.; Widlansky, M.E.; et al. Mitochondrial DNA damage and vascular function in patients with diabetes mellitus and atherosclerotic cardiovascular disease. Cardiovasc. Diabetol. 2016, 15, 53-60. [CrossRef] [PubMed]

60. Duan, Q.; Wang, T.; Zhang, N.; Perera, V.; Liang, X.; Abeysekera, I.R.; Yao, X. Propylthiouracil, Perchlorate, and Thyroid-Stimulating Hormone Modulate High Concentrations of Iodide Instigated Mitochondrial Superoxide Production in the Thyroids of Metallothionein I/II Knockout Mice. Endocrinol. Metab. 2016, 31, 174-184. [CrossRef] [PubMed]

61. Bragina, O.; Gurjanova, K.; Krishtal, J.; Kulp, M.; Karro, N.; Tougu, V.; Palumaa, P. Metallothionein 2A affects the cell respiration by suppressing the expression of mitochondrial protein cytochrome c oxidase subunit II. J. Bioenerg. Biomembr. 2015, 47, 209-216. [CrossRef] [PubMed]

62. Kang, Y.J.; Li, Y.; Sun, X.; Sun, X. Antiapoptotic effect and inhibition of ischemia/reperfusion-induced myocardial injury in metallothionein-overexpressing transgenic mice. Am. J. Pathol. 2003, 163, 1579-1586. [CrossRef] 
63. Bivik, C.; Ollinger, K. JNK mediates UVB-induced apoptosis upstream lysosomal membrane permeabilization and Bcl-2 family proteins. Apoptosis 2008, 13, 1111-1120. [CrossRef] [PubMed]

64. Haberzettl, P.; Hill, B.G. Oxidized lipids activate autophagy in a JNK-dependent manner by stimulating the endoplasmic reticulum stress response. Redox Biol. 2013, 1, 56-64. [CrossRef] [PubMed]

65. Xu, J.; Wang, G.; Wang, Y.; Liu, Q.; Xu, W.; Tan, Y.; Cai, L. Diabetes- and angiotensin II-induced cardiac endoplasmic reticulum stress and cell death: Metallothionein protection. J. Cell. Mol. Med. 2009, 13, 1499-1512. [CrossRef] [PubMed]

66. Liang, T.; Zhang, Q.; Sun, W.; Xin, Y.; Zhang, Z.; Tan, Y.; Zhou, S.; Zhang, C.; Cai, L.; Lu, X.; et al. Zinc treatment prevents type 1 diabetes-induced hepatic oxidative damage, endoplasmic reticulum stress, and cell death, and even prevents possible steatohepatitis in the OVE26 mouse model: Important role of metallothionein. Toxicol. Lett. 2015, 233, 114-124. [CrossRef] [PubMed]

67. Yang, L.; Hu, N.; Jiang, S.; Zou, Y.; Yang, J.; Xiong, L.; Ren, J. Heavy metal scavenger metallothionein attenuates ER stress-induced myocardial contractile anomalies: Role of autophagy. Toxicol. Lett. 2014, 225, 333-341. [CrossRef] [PubMed]

68. Kim, I.; Xu, W.; Reed, J.C. Cell death and endoplasmic reticulum stress: Disease relevance and therapeutic opportunities. Nat. Rev. Drug Discov. 2008, 7, 1013-1030. [CrossRef] [PubMed]

69. Gardner, O.S.; Shiau, C.W.; Chen, C.S.; Graves, L.M. Peroxisome proliferator-activated receptor $\gamma$-independent activation of p38 MAPK by thiazolidinediones involves calcium/calmodulin-dependent protein kinase II and protein kinase R: Correlation with endoplasmic reticulum stress. J. Biol. Chem. 2005, 280, 10109-10118. [CrossRef] [PubMed]

70. Boya, P.; Kroemer, G. Lysosomal membrane permeabilization in cell death. Oncogene 2008, $27,6434-6451$. [CrossRef] [PubMed]

71. Eno, C.O.; Zhao, G.; Venkatanarayan, A.; Wang, B.; Flores, E.R.; Li, C. Noxa couples lysosomal membrane permeabilization and apoptosis during oxidative stress. Free Radic. Biol. Med. 2013, 65, 26-37. [CrossRef] [PubMed]

72. Baird, S.K.; Kurz, T.; Brunk, U.T. Metallothionein protects against oxidative stress-induced lysosomal destabilization. Biochem. J. 2006, 394, 275-283. [CrossRef] [PubMed]

73. Ullio, C.; Brunk, U.T.; Urani, C.; Melchioretto, P.; Bonelli, G.; Baccino, F.M.; Autelli, R. Autophagy of metallothioneins prevents TNF-induced oxidative stress and toxicity in hepatoma cells. Autophagy 2015, 11, 2184-2198. [CrossRef] [PubMed]

74. Diaz-Ruiz, A.; Vacio-Adame, P.; Monroy-Noyola, A.; Mendez-Armenta, M.; Ortiz-Plata, A.; Montes, S.; Rios, C. Metallothionein-II inhibits lipid peroxidation and improves functional recovery after transient brain ischemia and reperfusion in rats. Oxid. Med. Cell. Longev. 2014, 20. [CrossRef] [PubMed]

75. Qi, M.; Elion, E.A. MAP kinase pathways. J. Cell Sci. 2005, 118, 3569-3572. [CrossRef] [PubMed]

76. Ceylan-Isik, A.F.; Zhao, P.; Zhang, B.; Xiao, X.; Su, G.; Ren, J. Cardiac overexpression of metallothionein rescues cardiac contractile dysfunction and endoplasmic reticulum stress but not autophagy in sepsis. J. Mol. Cell. Cardiol. 2010, 48, 367-378. [CrossRef] [PubMed]

77. Miao, X.; Tang, Z.; Wang, Y.; Su, G.; Sun, W.; Wei, W.; Li, W.; Miao, L.; Cai, L.; Tan, Y.; et al. Metallothionein prevention of arsenic trioxide-induced cardiac cell death is associated with its inhibition of mitogen-activated protein kinases activation in vitro and in vivo. Toxicol. Lett. 2013, 220, 277-285. [CrossRef] [PubMed]

78. Peng, Z.; Peng, L.; Fan, Y.; Zandi, E.; Shertzer, H.G.; Xia, Y. A critical role for IкB kinase $\beta$ in metallothionein-1 expression and protection against arsenic toxicity. J. Biol. Chem. 2007, 282, 21487-21496. [CrossRef] [PubMed]

79. Yang, L.; Gao, J.Y.; Ma, J.; Xu, X.; Wang, Q.; Xiong, L.; Yang, J.; Ren, J. Cardiac-specific overexpression of metallothionein attenuates myocardial remodeling and contractile dysfunction in 1-NAME-induced experimental hypertension: Role of autophagy regulation. Toxicol. Lett. 2015, 237, 121-132. [CrossRef] [PubMed]

80. Dhalla, N.S.; Temsah, R.M.; Netticadan, T. Role of oxidative stress in cardiovascular diseases. J. Hypertens. 2000, 18, 655-673. [CrossRef] [PubMed]

81. Nath, R.; Kumar, D.; Li, T.; Singal, P.K. Metallothioneins, oxidative stress and the cardiovascular system. Toxicology 2000, 155, 17-26. [CrossRef]

82. Giacconi, R.; Muti, E.; Malavolta, M.; Cipriano, C.; Costarelli, L.; Bernardini, G.; Gasparini, N.; Mariani, E.; Saba, V.; Boccoli, G.; et al. The $+838 \mathrm{C} / \mathrm{G}$ MT2A polymorphism, metals, and the inflammatory/immune response in carotid artery stenosis in elderly people. Mol. Med. 2007, 13, 388-395. [CrossRef] [PubMed] 
83. Yang, X.; Doser, T.A.; Fang, C.X.; Nunn, J.M.; Janardhanan, R.; Zhu, M.; Sreejayan, N.; Quinn, M.T.; Ren, J. Metallothionein prolongs survival and antagonizes senescence-associated cardiomyocyte diastolic dysfunction: Role of oxidative stress. FASEB J. 2006, 20, 1024-1026. [CrossRef] [PubMed]

84. Ren, J. Endoplasmic reticulum stress impairs murine cardiomyocyte contractile function via an Akt-dependent mechanism. Circulation 2007, 116, 74.

85. Guo, R.; Ma, H.; Gao, F.; Zhong, L.; Ren, J. Metallothionein alleviates oxidative stress-induced endoplasmic reticulum stress and myocardial dysfunction. J. Mol. Cell. Cardiol. 2009, 47, 228-237. [CrossRef] [PubMed]

86. Trendelenburg, G.; Prass, K.; Priller, J.; Kapinya, K.; Polley, A.; Muselmann, C.; Ruscher, K.; Kannbley, U.; Schmitt, A.O.; Castell, S.; et al. Serial analysis of gene expression identifies metallothionein-II as major neuroprotective gene in mouse focal cerebral ischemia. J. Neurosci. 2002, 22, 5879-5888. [PubMed]

87. Jakovac, H.; Tota, M.; Grebic, D.; Grubic-Kezele, T.; Barac-Latas, V.; Mrakovcic-Sutic, I.; Milin, C.; Radosevic-Stasic, B. Metallothionein I+II expression as an early sign of chronic relapsing experimental autoimmune encephalomyelitis in rats. Curr. Aging Sci. 2013, 6, 37-44. [CrossRef] [PubMed]

88. Miyazaki, I.; Asanuma, M.; Murakami, S.; Takeshima, M.; Torigoe, N.; Kitamura, Y.; Miyoshi, K. Targeting 5-HT(1A) receptors in astrocytes to protect dopaminergic neurons in Parkinsonian models. Neurobiol. Dis. 2013, 59, 244-256. [CrossRef] [PubMed]

89. Kelly, E.J.; Quaife, C.J.; Froelick, G.J.; Palmiter, R.D. Metallothionein I and II protect against zinc deficiency and zinc toxicity in mice. J. Nutr. 1996, 126, 1782-1790. [PubMed]

90. Jin, R.; Chow, V.T.; Tan, P.H.; Dheen, S.T.; Duan, W.; Bay, B.H. Metallothionein 2A expression is associated with cell proliferation in breast cancer. Carcinogenesis 2002, 23, 81-86. [CrossRef] [PubMed]

91. Lim, D.; Jocelyn, K.M.; Yip, G.W.; Bay, B.H. Silencing the Metallothionein-2A gene inhibits cell cycle progression from G1- to S-phase involving ATM and cdc25A signaling in breast cancer cells. Cancer Lett. 2009, 276, 109-117. [CrossRef] [PubMed]

92. Liu, T.P.; Hong, Y.H.; Tung, K.Y.; Yang, P.M. In silico and experimental analyses predict the therapeutic value of an EZH2 inhibitor GSK343 against hepatocellular carcinoma through the induction of metallothionein genes. Oncoscience 2016, 3, 9-20. [PubMed]

93. Mehrian-Shai, R.; Yalon, M.; Simon, A.J.; Eyal, E.; Pismenyuk, T.; Moshe, I.; Constantini, S.; Toren, A. High metallothionein predicts poor survival in glioblastoma multiforme. BMC Med. Genom. 2015, 8. [CrossRef] [PubMed]

94. Pan, Y.; Lin, S.; Xing, R.; Zhu, M.; Lin, B.; Cui, J.; Li, W.; Gao, J.; Shen, L.; Zhao, Y.; et al. Epigenetic Upregulation of Metallothionein 2A by Diallyl Trisulfide Enhances Chemosensitivity of Human Gastric Cancer Cells to Docetaxel Through Attenuating NF-кB Activation. Antioxid. Redox Signal. 2016, 24, 839-854. [CrossRef] [PubMed]

95. Pan, Y.; Huang, J.; Xing, R.; Yin, X.; Cui, J.; Li, W.; Yu, J.; Lu, Y. Metallothionein 2A inhibits NF-kB pathway activation and predicts clinical outcome segregated with TNM stage in gastric cancer patients following radical resection. J. Transl. Med. 2013, 11. [CrossRef] [PubMed]

96. Starska, K.; Krześlak, A.; Forma, E.; Olszewski, J.; Lewy-Trenda, I.; Osuch-Wójcikiewicz, E.; Bryś, M. Genetic polymorphism of metallothionein 2A and risk of laryngeal cancer in a Polish population. Med. Oncol. 2014, 31. [CrossRef] [PubMed]

97. Habel, N.; Hamidouche, Z.; Girault, I.; Patino-Garcia, A.; Lecanda, F.; Marie, P.J.; Fromigue, O. Zinc chelation: A metallothionein 2A's mechanism of action involved in osteosarcoma cell death and chemotherapy resistance. Cell Death Dis. 2013, 4, e874. [CrossRef] [PubMed]

98. Evangelou, K.; Havaki, S.; Kotsinas, A. E2F transcription factors and digestive system malignancies: How much do we know? World J. Gastroenterol. 2014, 20, 10212-10216. [CrossRef] [PubMed]

99. Mocchegiani, E.; Costarelli, L.; Giacconi, R.; Cipriano, C.; Muti, E.; Malavolta, M. Zinc-binding proteins (metallothionein and alpha-2 macroglobulin) and immunosenescence. Exp. Gerontol. 2006, 41, 1094-1107. [CrossRef] [PubMed]

100. Kayaalti, Z.; Sahiner, L.; Durakoglugil, M.E.; Soylemezoglu, T. Distributions of interleukin-6 (IL-6) promoter and metallothionein 2A (MT2A) core promoter region gene polymorphisms and their associations with aging in Turkish population. Arch. Gerontol. Geriatr. 2011, 53, 354-358. [CrossRef] [PubMed]

101. Cruz, K.J.; de Oliveira, A.R.; Marreiro Ddo, N. Antioxidant role of zinc in diabetes mellitus. World J. Diabetes 2015, 6, 333-337. [CrossRef] [PubMed] 
102. Giacconi, R.; Cipriano, C.; Muti, E.; Costarelli, L.; Maurizio, C.; Saba, V.; Gasparini, N.; Malavolta, M.; Mocchegiani, E. Novel -209A/G MT2A polymorphism in old patients with type 2 diabetes and atherosclerosis: Relationship with inflammation (IL-6) and zinc. Biogerontology 2005, 6, 407-413. [CrossRef] [PubMed]

103. Nakazato, K.; Tomioka, S.; Nakajima, K.; Saito, H.; Kato, M.; Kodaira, T.; Yatsuzuka, S.; Shimomura, Y.; Hiroki, T.; Motoyama, K.; et al. Determination of the serum metallothionein (MT) $1 / 2$ concentration in patients with Wilson's disease and Menkes disease. J. Trace Elem. Med. Biol. 2014, 28, 441-447. [CrossRef] [PubMed]

104. Xu, X.; Shi, F.; Huang, W.; Kang, Y.J. Metallothionein gene transfection reverses the phenotype of activated human hepatic stellate cells. J. Pharmacol. Exp. Ther. 2013, 346, 48-53. [CrossRef] [PubMed]

105. Tsuji, T.; Naito, Y.; Takagi, T.; Kugai, M.; Yoriki, H.; Horie, R.; Fukui, A.; Mizushima, K.; Hirai, Y.; Katada, K.; et al. Role of metallothionein in murine experimental colitis. Int. J. Mol. Med. 2013, 31, 1037-1046. [PubMed]

(C) 2016 by the authors; licensee MDPI, Basel, Switzerland. This article is an open access article distributed under the terms and conditions of the Creative Commons Attribution (CC-BY) license (http://creativecommons.org/licenses/by/4.0/). 